\title{
The Visualization of Wayang Kulit Purwa by Bambang Suwarno
}

Bagaskoro Ardhi, Slamet Supriyadi, and Edy Tri Sulistyo

Postgraduate Program of Art Education

Universitas Sebelas Maret Surakarta

36th-A Ir. Sutami Street, Kentingan, Surakarta 57126

Phone/Fax (0271) 632450

Volume 6 Nomor 2,

Oktober 2019: 101-111

Tlp.085799416907,E-mail: bgatsz92@gmail.com

\begin{abstract}
ABSTRAK
Visualisasi Wayang Kulit Purwa Karya Bambang Suwarno. Artikel ini membahas tentang visualisasi wayang kulit purwa karya Bambang Suwarno, seorang dalang, guru dalang, dan pengembang pakeliran padat. Tujuan penelitian ini adalah mengetahui visualisasi wayang kulit karya Bambang Suwarno. Metode yang digunakan adalah bentuk deskriptif kualitatif. Teknik pengumpulan data yang digunakan peneliti dalam penelitian ini adalah teknik observasi, wawancara dan dokumentasi. Hasil kreativitas berkarya ditunjukkan dalam berbagai karya wayang dari kondisi yang ambang, ricuh, dan mencoba sesuatu yang belum ada dari berbagai jenis tokoh wayang. Pengakuan berbagai tanggapan dalang tentang karya kreasi ini menunjukkan kreativitas berkarya yang memiliki konsep, dan mendukung pentas pakeliran. Selain itu, diharapkan wayang semakin indah dilihat, menjadi penghubung antar tokoh dalam lakon, memenuhi sanggit pakeliran, menambah perbendaharaan tokoh wayang, dan memperkuat pengakuan wayang di mata dunia.
\end{abstract}

Kata kunci: wayang kulit purwa; Bambang Suwarno

\begin{abstract}
This article discusses the visualization of wayang kulit purwa by Bambang Suwarno, a puppet master (dalang), a puppet master's teacher, and a developer of a short shadow puppet performance. The objective of the research is to find out the visualization of wayang kulit by Bambang Suwarno. The method employed was descriptive qualitative one. Techniques of data collection were observation, interview, and documentation. The result of working creativity could be seen in many wayang works from the threshold, chaotic condition to trying something new that has never existed yet in a variety of wayang characters. Recognition of various mastermind's responses to the work of Bambang Suwarno indicted the creativity of work that has a concept, and supports the performance stage. In addition, it is hoped that wayang will be more attractive to watch, become a liaison between characters in the play, fulfill the sanggit pakeliran, increase the treasury of puppet characters, and strengthen the puppet recognition in the world.
\end{abstract}

Keywords: wayang kulit purwa; Bambang Suwarno

\section{Introduction}

One of the masterpieces of cultural heritage that must be preserved from generation to generation is Wayang Kulit. The term wayang in Malayan was called "Bayang-bayang" (shadow). Wayang in Javanese means "shadow" (Mulyono, 1978: 11).
Shadow puppet is a popular art product which developes in Java, not only in Central Java, but also in other regions such as Yogyakarta, West Java, East Java, even in Bali. Shadow puppets especially grow as a cultural product from the cultural center of the palace, so it can be said that the art of shadow puppets performance is a product of the court culture. The existence of puppets from old times 
to the present Indonesia has a connection on the historical development of power in Java (Masroer, 2015: 42).

Handoko in Dyah Pandanwangi et al (2018: 2) explained that wayang is the identity of the Javanese community, its performance featuring figures who have their own characters. Therefore, wayang is also a reflection of one's soul. Wayang has been established as the Masterpiece of the Oral and Heritage of Humanity by the United Nations through UNESCO on November 7, 2003, because this shadow puppets performance is considered to have high values for human civilization. The opinion that stated shadow puppets as a Masterpiece of Oral and Intangible Heritage of Humanity was based on six conditions, they are (i) Extraordinary value as a masterpiece of human creation. (ii) Established firmly in the cultural traditions or cultural history of the community concerned. (iii) Acting as a means of expressing the identity of the nation or ethnic group concerned, which serves as a source of inspiration for cultural exchange, as a means of bringing people closer to one another, and their present social role in the community concerned. (iv) The use in the application of the skills and technical properties exhibited. (v) Its role as a living cultural tradition. (vi) The risk of extinction due to the lack of means to preserve and protect it (Wibisono in Nurgiyantoro, 2011: 20-21).

Bambang Suwarno is one of the puppet master who played a role in developing pakeliran padat. Bram Setiadi and Amin Pujianto (2011) added that Bambang Suwarno also played a role in the development of new shadow puppet figures, which still had the basis of classical puppets that had existed. With the addition of elements such as tatahan and sunggingan, the new figures are expected to be the shadow puppets creation that can be unified with existing puppets, with the aim of adding to the treasury and bridging classical puppets with puppet creations. Some classical shadow puppets that experienced the development of the work from Bambang Suwarno works includes some of the gunungan, namely Pawukon, Purwaning Dumadi, Sewu Manis, Hakekat, Lingkungan Hidup, Klowong, Jagad Raya Gumelar, and Gunungan Samodra Mantana (p. 18).
Pandam Guritno said that shadow puppets has long been developing in Indonesia, at least since the $10^{\text {th }}$ century, and was called ringgit. At the time it was not yet known as a wayang kulit purwa performance with walulang (animal skin type) that inukir (carved or inlaid) as the material (Sunarto, 2006: 40). Bambang Suwarno, in his book collection of Kajian Estetik Wayang Kulit (1996: 3) adds that Javanese have inherited a form of aesthetic observation towards shadow puppets for a long time. The ideas of the embodiment of each shadow puppet character was obtained from the description of puppet masters' sense and the anatomical shapes of puppet characters that we have seen. Haryanto in the book Pratiwimba Adiluhung: History and Development of Puppets (1988: 48) mentions that wayang purwa is a performance that shows a story that originates from Mahabharata or Ramayana books. In Javanese society, the term purwa can be interpreted as primordial or ancient. According to this understanding, wayang purwa is defined as a shadow puppet (wayang) that presents ancient stories or purwa.

The forms of art that were originally proportionately realistic as found in the temples are distillated into abstract imaginative forms, in the sense that they remain proportional, but not human. Wali meticulously developed the Islamic art world of shadow puppet, but remained in harmony with the development of society at that time (Solichin in Heru Sudjarwo et.al, 2010: 52). The proportion of wayang kulit purwa in general possessed the ratio of $1: 4$ or $1: 3$ between head and body, therefore, the head looks bigger. Hands on the puppets starting from the shoulders and down almost touching the soles of the feet, it becomes very long when compared to human proportions, and both legs appear longer when associated with the head and body (Haryanto, 1991: 32).

Periodizing further developments with the inclusion of Hindu-Buddhist religion, the shadow puppets function as a tool to describe ancestors. It should also be noted that, although Hindu-Buddhist religion has entered, respect for the ancestral spirits rituals continues in order not to cause a curse or "kuwalat". From this ritual, the 
Javanese then create wayang, where the ancestors were described as figures of the shadow puppets.

Based on Javanese books such as Centhini and Sastramirudha, it was explained that wayang purwa existed in the days of Prabu Jayabaya in Mamenang (939 AD) drawn on palm leaves. Puppets in those days were still closely related to religious functions to worship or commemorate their deceased ancestors (Soetarno, et. al. 2007: 9). With the advent of Islam, the history of shadow puppets art in Indonesia underwent a process of development with all the provisions of the Indonesian-Islamic fine arts tradition. During this period, wayang forms were born which reflected a mature conception in accordance with Indonesian artistic, visual and spiritual traditions (Haryanto, 1991: 25).

Apart from its performance, wayang kulit can be seen in terms of the beauty of the wayang form. The basic medium of "appearance", in addition to other basic media such as motion, sound, and language are used in the world of shadow puppets. All of the media support each other to increase the quality of the performance. In the world of wayang, "wanda" as one of the elements of the visual medium, plays an important role in strengthening the sense of a character. The sense of stability is supported by voices, sanggit, sabet, sulukan, and so forth. The use of wanda depends on the atmosphere that the shadow puppet plays to add to the atmosphere of the staging scene. Of course the use of wanda is based on the conventional habits of the puppet master of earlier times. However, today with a limited number of specific puppet the puppet master owned and few references about wanda, the puppet masters rarely concerned with wanda anymore (Sutarno et. al, 1978/1979: 1). Furthermore, Purwadi (2007: v) revealed the puppetry art of wayang purwa includes several kinds of aesthetic elements in it, including dance, fine arts, sound arts, music, drama, and literary arts. Each of these elements is combined into one, forming an amazing beauty, and is expected to make the value of Edi Peni and Adi Lubung.

Wanda can be interpreted as a visible manifestation of the mood or depictions of the face of the puppet character (Java: Pasemon)
(Sudarso Sp in Heru Sudjarwo et. al, 2010: 22). Wanda position is located in the highest aesthetic region in appreciating wayang (Heru Sudjarwo et. al, 2010: 21). The use of the embodiment of characters in wayang, including wanda, further add to the atmosphere of the shadow puppet performance (Haryanto, 1991: 270).

Artworks are born because there are artists who create those works called representations. Representation is an attempt to reveal the truth or reality of the universe as found by artists. The creation of works of art is a serious work, which requires careful thought and hard work, data observations, and sharp intuition in seeing the truth (Sumardjo, 2000: 79). It is explained further that the creativity of the artist in the work reveals a threshold condition, that condition between existing and not existing. Therefore, a creative person is always in a chaotic, critical condition, searching, trying to find something that has never existed from the existing order. Therefore, the creativity is required in terms of creative courage ( $p$ 80). Creative courage requires the discovery of new forms, new symbols, and new patterns (May, 2004: 12).

Susanto (2011: 229) stated that creativity is a process of making something new, with a new perspective. Djelantik stated that the formation of creativity involves something that its "art" has never been realized before. The "art" contains meaning. Therefore, self-creation is making something that did not yet exist into existence, not only a new form, but a renewal of the aesthetic concept, or a very new discovery (Suseno, 2014: 117). Creativity requires to create new combinations both in ideas, forms, and new production and departs from existing traditions (Evans, 1991: 1).

Referring to the explanation above, the purpose of this study is to know the visualization of the creation of wayang kulit purwa by Bambang Suwarno located at Sungai Musi number 34 Sangkrah, Pasar Kliwon, Surakarta, as the main data source. Based on the problem studied, this study uses a descriptive qualitative form. Moleong (2013: 6) explains that qualitative research is intended to understand the phenomena experienced by research subjects by means of descriptions in the form of words and language. 
Qualitative research uses qualitative methods, namely observations, interviews, or document review. Data collection techniques used by researchers in this study were observation, interviews and documentation. Observation was used to show the manifestation of Bambang Suwano's wayang purwa creation. Observation included using participatory observation techniques. Interviews were carried out to find out a complete information from speakers involved in it, which included Bambang Suwarno's work as well as forms of the puppets created by Bambang Suwarno. The interviews were conducted to several speakers including Bambang Suwarno as the main interviewee, and supported by some interviewees such as Manteb Soedharsono, Purbo Asmoro, Blacius Subono, Narimo, Suluh Juni Arsah, and Rudy Wiratama. Documentation aims to support observation and interviews in addition to documenting the search for Bambang Suwarno's works.

The research strategy used was snowball sampling techniques or referral chains, demanding that the first interviewees met by researchers be the key to using their social networks to refer researchers to other people who have the potential to participate or contribute and learn or provide information to researchers (Bungin, 2007: 108). According to Sutopo (2002: 57) the process of snowball sampling work was likened to a snowball that begins with very small ball, rolling farther on the slopes of snow and becoming increasingly dense and large. This is done because the number of data sources has not been able to provide data satisfactorily, therefore, searching for other data sources as a complement in research was required. Complementary to various informants aimed at finding answers thoroughly from various points of view.

\section{Bambang Suwarno's Work}

The existing, creative, and innovative forms are needed by artists to show one's identity, especially in creating. The creativity of artist in their work expresses a threshold condition, namely the condition of existing and not existing. In relation to art, artists work in accordance with their freedom, of course, to search, explore, and try something new that has never existed before. Bambang Suwarno's form of creativity is aimed at making works to support performances. Bambang Suwarno is strong with elements of tradition in his works, but remains critical, and gives rise to new values. The same thing was expressed by Sumardjo (2000: 90), a traditional artist who is critical in trying to find new values in traditional works of art. This is what is called by masterpiece.

The disclosure theories by Benedetto Croce mention the theory of creation is the disclosure of impressions. The process of expressing impressions takes place entirely in the mind of the artist, while the work of art produced is only a kind of memorandum, copy, or reproduction of whatever is experienced by the artist (Gie, 2004: 33). Art communication theory, art works as an intermediary between artists and recipients of art. This trilogy is related to one another.

One of the goals of the creation of wayang kulit purwa variants is to fulfill the demands of the scenes in the play. The goal is considered very important because it helps the puppet masters in playing the position, how to convey the messages in the form of figure and performance to the community, thereby it creates its value of mungguh (appropriate) in its pakeliran (vocal and instrumental set).

Manteb Soedharsono as the shadow puppet performer, especially as the puppet master, stated that the puppet master or individual has the right to have authority in making characters, but must be adjusted to the character of the puppet characters (interview on June 13, 2018 at 16.00). When the form of characterization is known to the general public, it will be easily recognized, therefore, without using a substitute puppet it will be ambiguous. Another opinion expressed by Purbo Asmoro (interview on November 8, 2018, 15:00), emphasizing in its pakeliran when using a replacement puppet characters, then the value is valid. The village puppet masters in the past, for example, only had one or two Arjuna figure. Another example is when the Lesmana figure does not exist, then it can be replaced by a Permadi figure (young Arjuna). Basically, the influence of wanda was born in the palace environment. 
Blacius Subono (interview dated on October 22, 2018 at 12:15) adds that actually Bambang Suwarno's works had a certain type and need a mature concept. In making puppets, Bambang Suwarno made careful consideration and thought. In addition, Bambang Suwarno's puppet works are based on plays that will be staged, even when other puppet masters ask for puppet assistance, Bambang Suwarno is reluctant to make puppet works. Examples of the narrative work of shadow puppet created by Bambang Suwarno is Murwakala performance, Blacius Subono performance and Kalabendu, and Blacius Subono performance in Central Java Cultural Park (TBJT) Surakarta (interview with Blacius Subono, dated October 22, 2018 at 12:15). This was supported by Narimo (interview dated on November 30, 2018 at 10.30) with the existence of a puppet creation by Bambang Suwarno who became an intermediary for other puppets, it would give the impression gained in the event or play.

Manteb Soedharsono showed more arguments (interview dated on June 13, 2018 at 16.00), where the addition of the puppet character becomes a separate container in the world of wayang, making the puppet show more interesting and reinforces the recognition of wayang as a result of Indonesian cultural arts in the eyes of the world. Similarly, Suluh Juni Arsah (interview dated on November 12, 2018 at 14.10) argued that Bambang Suwarno, as an artist departed from tradition, trying to solve and provide solutions to the realization of puppet creations. Suluh further explained that there were still gaps that could still be filled by Bambang Suwarno's works but were not lame with the established puppets. Examples of Bambang Suwarno's works that have been circulating among puppet masters and wayang artisans include Kayon Klowong and Kayon Hakekat.

The example of Bambang Suwarno in developing artistic puppet to try something new that serves as an intermediary play with each other and is a Sanggit requirement. As in the transition of Rama Bargawa, the Rama Bargawa created by Bambang Suwarno was manifested in two versions, namely the young Rama Bargawa when he was still a royal family of Maèspati, and Rama Bargawa after leaving the kingdom because of the behavior of his mother, Dewi Renuka, who had an affair with Maespati's retainer, Raden Citranggada. The clothing worn by Rama Bargawa in general is a modest clothing, with pants, without bracelets, necklaces, and with loose hair, this is how Bambang Suwarno imagined of the character in developing the character of Rama Bargawa in accordance with the play or events experienced by certain puppet figures. There are many more examples of usage and other interests that could be used by a puppet master to increase the beauty of its pakeliran.

Here are some explanations for wayang created by Bambang Suwarno,

\section{Kayon Klowong}

a. Background

The shape of Kayon Klowong (figure 1) has the shape of a kayon or gunungan (like mountain) that is smaller than the size of a gunungan in general. The Kayon Klowong by Bambang Suwarno have the size of $43.5 \mathrm{~cm}$ x $65.5 \mathrm{~cm}$ on the outer side. Kayon Klowong was created in 1986 to support the Trisno Santoso stage with the play of Rama Bargawa (Kurniawan, 2008: 93). the initial name of Kayon Klowong is Kayon Kabut Sutera Ungu (interview with Rudy Wiratama, dated on April 15, 2018 at 18.00). Kayon Klowong form has been widely spread among the puppet masters.

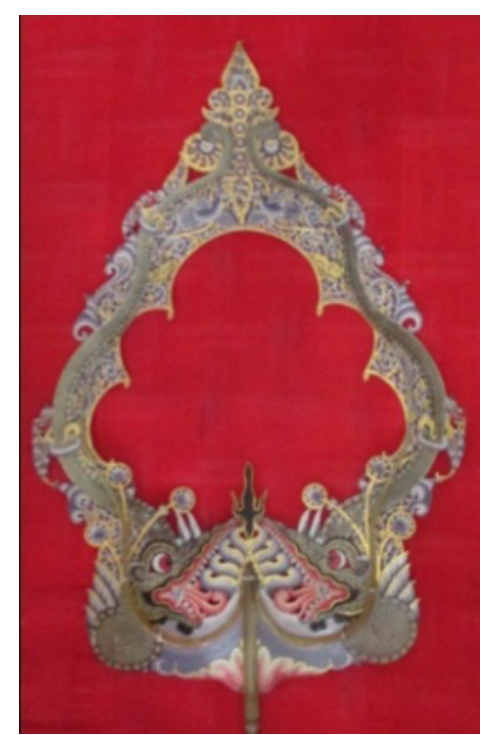

Figure 1. The Kayon Klowong made in 1986 with the outer side $43.5 \mathrm{~cm} \times 65 \mathrm{~cm}$, collected by Bambang Suwarno. (Source: Bagaskoro Ardhi, 2019) 


\section{b. Description of the Work}

The contour on the right and left side of the Kayon Klowong occurs because the body is formed of a dragon and vines as isen-isen to the top of Kayon. The bottom impressed with the dragon ornaments. The embodiment of the dragons ornament seems the same between the right and left sides facing each other with the mouth open with fangs and blazing eyes. In the middle of the dragon and the bottom of the palemahan there is a lotus flower ornament, and on top of the lotus flower ornament there is a trident ornament. The top is decorated by fauna ornaments in the form of butterflies and birds.

The Sunggingan is dominant with golden purple color. The shape of the cempurit is split into two, and it twists in the direction of the kayon following the dragon's body (Budiyatmi, 2004: 83). There is a hole in the structure of the apex and body structure (Java: genukan). The form of utilization of chisel elements carved through to the rear, the utilization of sungging adjust the motif on its Kayon klowong. The edge of the hole in the puddle merges like a cloud.

The use of Kayon Klowong in The Banjaran Prabu Airlangga play by Bambang Suwarno at the Surakarta City Hall is to show the focus on the marriage of the figures of Airlangga and Retna Galuh (see figure 2).

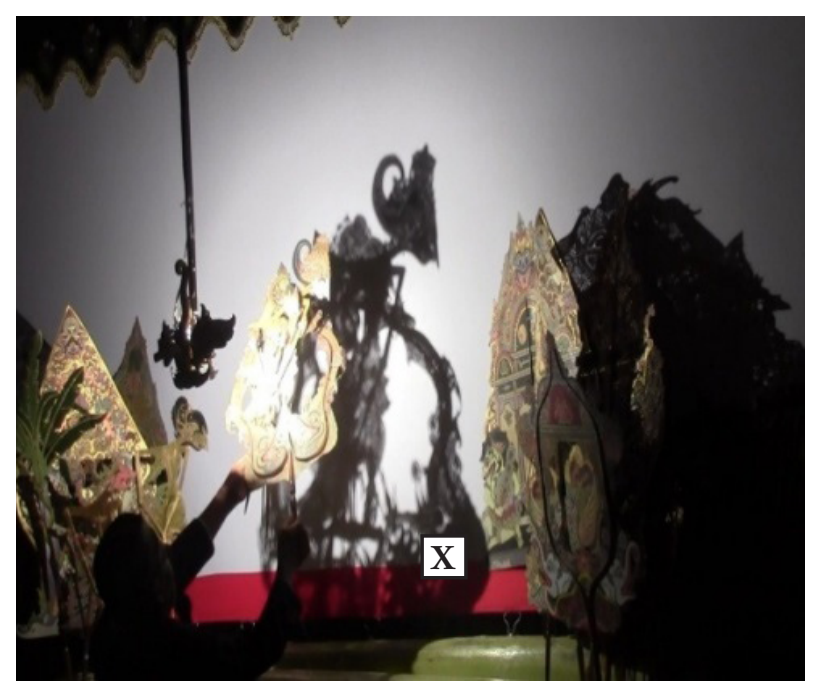

Figure 2. Kayon Klowong (X) to show the focus of the wedding of Airlangga and Retna Galuh figures in Surakarta City Hall on January $25^{\text {th }}, 2019$. (Source: Bagaskoro Ardhi, 2019)

\section{Kayon Hakekat}

a. Background

Figure Kayon Hakekat created in 1987 is a creative form of Kayon or mountains. Kayon Hakekat is smaller than the mountains in general. Kayon Hakekat measures the outer edge with $34.5 \mathrm{~cm}$ x $58.5 \mathrm{~cm}$. Kayon Hakekat is widely spread among the puppet masters.

b. Description of the Work

The shape of Kayon Hakekat (figure 3) is a development of Kayon or gunungan in general. Kayon Hakekat describes the life of harmony among religions, which share a single mound. The diversity of religions includes Islam, Christianity, Catholicism, Hinduism, and Buddhism.

The contours on the part formed in a straightforward manner without the edge of the gunungan. A hole is made in the center part intentionally to add to the aesthetic shape of the kayon. The elements at the bottom of the gunungan are formed from water stylation which forms like a cloud. At the bottom there is a snake that is spiraling with the head facing the upper right, while the tail is facing the lower left. On the left and right of the snake there are two winged humans. On top of the spiral-shaped snake ornament is a stylized ornament resembling a stupa that connects the bottom and the

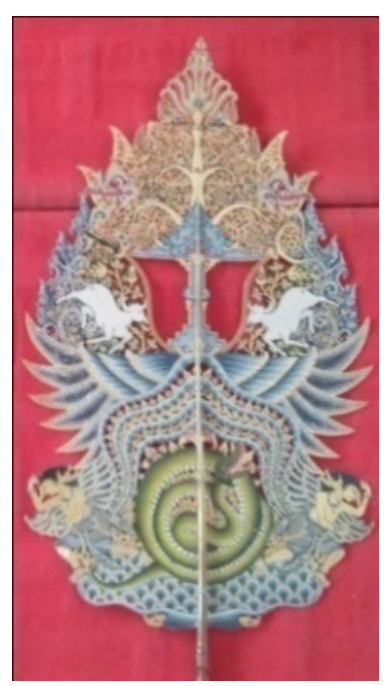

Figure 3. Kayon Hakékat created in 1987 with the outer side sized on $34 \mathrm{~cm} \times 58.5 \mathrm{~cm}$, collection of Bambang Suwarno. (Source: Bagaskoro Ardhi, 2019) 
middle. The right and left sides of the stupa ornament have the impression that there are wings stretch outwards. Tuwung or trophy of offerings (place of the water cup) is located in the middle of the hole that has been perforated (Budiyatmi, 2004: 77).

The middle of the tuwung is connected by Banaspati who sticks out his tongue forming a cross element connected with the tip of the tuwung in the form of a crescent arrow (Pasopati) on the right side and a threepointed arrow (trident) on the left side. On the left and right sides of the tuwung there are two sheep ornaments that swoop down to the end of the stupa. Various flora ornaments became the background of sheep ornaments. At the top there is a six-branched tree, each with three on the right and three on the left part, which is decorated with the carving and ornamentation of leaves. Fauna ornaments found in the leaves include two birds, two caterpillars, and two butterflies. There is also an eagle ornament on the left and right of Kayon Hakekat with utahutahan segara Muncar. At the top of the mountain there are flowers that bloom with the flower buds facing up.

Kayon Hakekat is used to supportpakeliran padat lakon Dewa Ruci and ciptoning by Bambang Suwarno in 1987 (Didik Kurniawan, 2008: 95). The Kayak Hakekat on the play of Srikandi Maguru Manah on April $19^{\text {th }}, 2019$ on Jalan Sungai Musi number 34 Sangkrah, Pasar Kliwon, Surakarta showed a

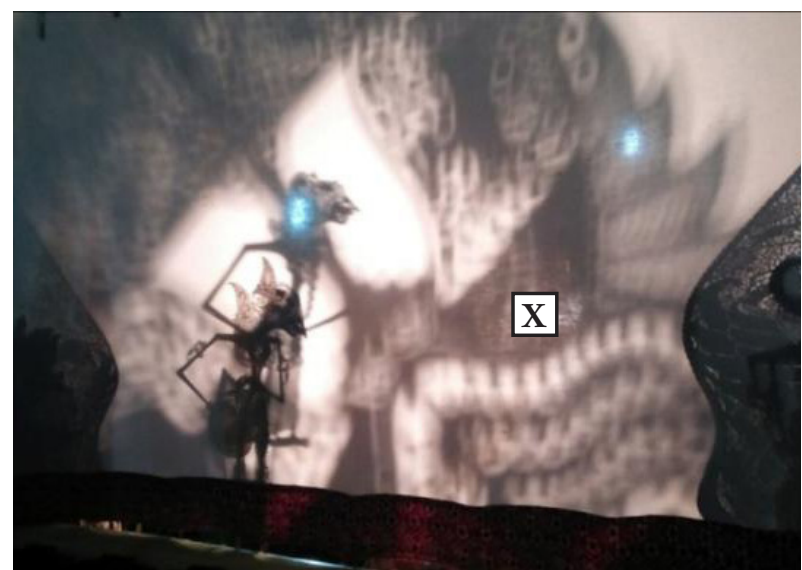

Figure 4. Kayon Hakekat (X) to show the focus of King Jungkung Mardeya imagining Srikandi. (Source: Bagaskoro Ardhi, 2019) focus on Prabu Jungkung Mardeya imagining Srikandi (figure 4).

\section{Kunthi Wanda Nggarbini}

a. Background

The procurement of these puppet figures is to support the pakeliran padat in Kunthi Pilih play. Kunthi wanda nggarbini can be interpreted as a figure of Kunthi who is pregnant (Didik Kurniawan, 2008: 99).

b. Description of the Work

The figure of Kunthi wanda nggarbini (figure 5) was made in 1986. The puppet figure creation of Kunthi used the basic of putren luruh, nose of wali miring, eyes of gabahan, the mouth is closed with lambe kinangan with keketan. Earring uses slobog, sumping (earlobe ornament) uses sumping waderan with jamang sada saélér. Kunthi figure use ukel sangkon gendhong extending to the legs and front part of the body. The kancing gelung ornates uses karang melok.

The neck part uses a mayat where the neck is inclined towards the front with $30^{\circ}$ angle. The neck part is connected to the pundhak mlered. Necklace ornament formed by non penetrated carving. The neck uses the shape of the stomach that seems to fall backwards. The clothing used is in the form of samparan that seems slack. The kemben (torso wrap) uses udet sembuliyan landhung that seems long and the footsteps seem wide. The accessories on the hand only use the gunung sapikul ring, while the foot do

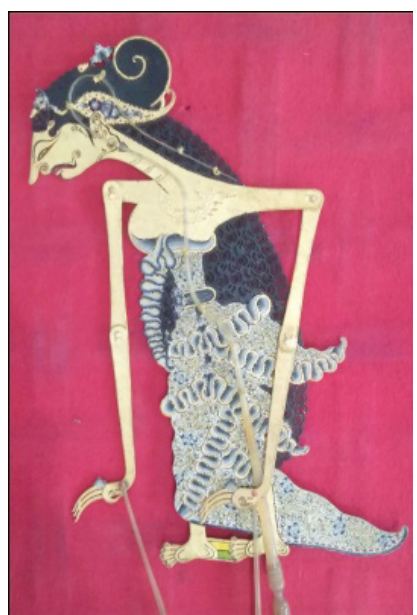

Figure 5. Kunthi Wanda Nggarbini made in 1986, by Bambang Suwarno. (Source: Bagaskoro Ardhi, 2019) 
not wear anklets. The impression that arises in the part of hair that covers the body seems to have volume that it reflects an enlarged abdomen. The Kunthi of wanda nggarbini has a depiction of Kunthi who is pregnant.

Blacius Subono (interview dated on October 22, 2018, at 12:15) revealed that its form was actually like an ordinary princess figure, but was processed by Bambang Suwarno that its form appeared to be someone who is pregnant and had a volume with the support of strands of hair that extend to the body.

Furthermore, Purbo Asmoro (interview dated on June 4, 2018 at 14.00) stated that not only Kunthi, but this new figure can be used as another princess figure who has a whole character with a bowing puppet figure like Sinta, Drupadi, Sembadra, and others.

4. Harya Suman (transition to the original form of Sengkuni)

a. Background

Harya Suman is the young name of Sengkuni. The figure of Harya Suman depicts the figure of a bambangan lanyap whose eyes are gabahan (aloof). Harya Suman's transition with Sengkuni was manifested by the creation of Bambang Suwarno's puppet with a form like Sengkuni, but it was not bearded and did not use kethu (hat).

This figure was made to support the Gandamana Luweng performance, after Harya Suman's handsome appearance was

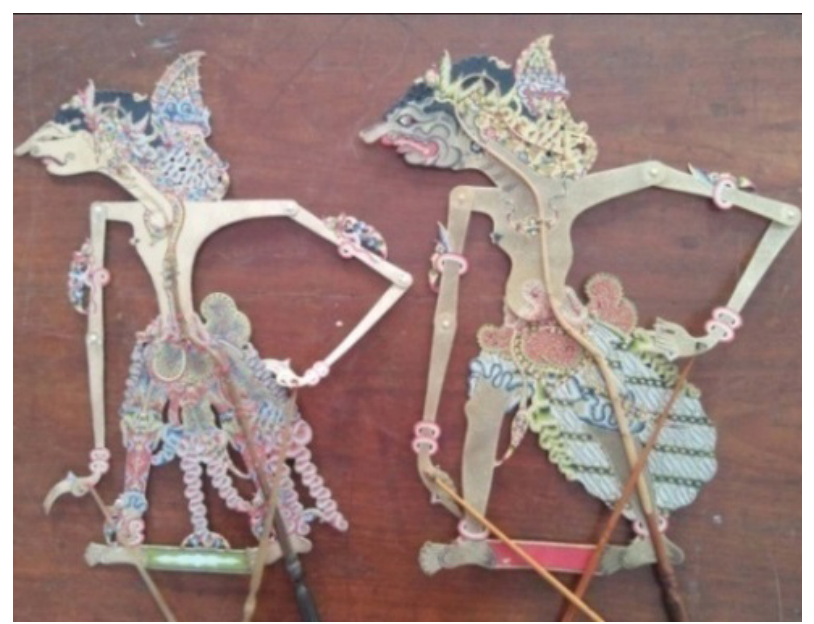

Figure 6. The transition from Harya Suman (left) to Sengkuni's initial form (right), Bambang Suwarno's puppet collection. (Source: Bagaskoro Ardhi, 2018) beaten by Gandamana because he manipulated Gandamana. Transition of the figure of Harya Suman's creation to Bambang Suwarno's Sengkuni form was caused by a form that adapts the Gandamana Luweng play, where the transition from the Harya Suman form (with a handsome face) to the initial Sengkuni form (see figure 6) that already exists. Therefore, it is necessary to add characters as an intermediary between characters to increase the treasury of the puppet.

b. Description of the Work

The description of Harya Suman transitional forms to the original form of Sengkuni by Bambang Suwarno: nose of pangotan tunggul, eyes of kedondongan gazed backward, mouth of gusen tanggung, Lambe gubel, teeth of gigisan or grontolan with fangs in the corners of the mouth, forehead of sinom rikma rengon, earrings of sekar Sruni, diadem of calumpringan, earlobe ornaments of sekar kluwih, diadem strap of gladren, double-edged garudha Mungkur facing backwards with long utah-utahan karawistha, parts of hat with the shape of irah-irahan pogokan.

A mapak-type neck where the neck is around 45 degrees, haughty shoulder, slouching stomach that is leaning forward, and using kalung penanggalan (figure 7). The belt ties of suwelan types which is almost used by kings, nobles, and giants (Haryanto, 1991: 111).

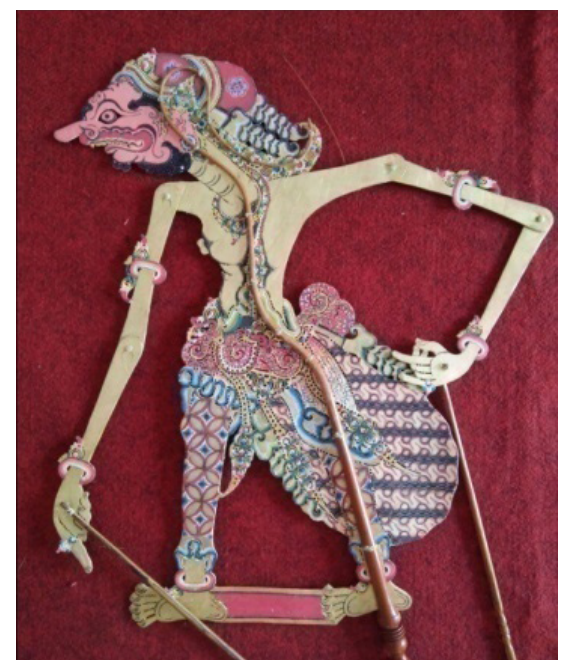

Figure 7. Adult Sengkuni, Bambang Suwarno collection. (Source: Bagaskoro Ardhi, 2018) 


\section{Kayon Sona Srenggala}

a. Background

Gunungan or Kayon Sona Srenggala is the main visual domination of buffaloheaded human form driven by dog-headed human. The idea of the creation comes from Mardi Subroto (uncle of Bambang Suwarno), who is a puppet master himself and also a spiritualist. Kayon Sona Srenggala is made for the purpose of staging the inaugural stage February 1, 2014 at Pangudi Luhur High School Don Bosco Semarang. The terms Sona and Srenggala in Javanese Kawi are the synonyms/equivalent of the word $\mathrm{dog}$ in Javanese (Suparlan, 1988: 266-267).

b. Description of the Work

The shape of Kayon Sona Srenggala (figure 8) is described as follows: Kayon form use asymmetrical balance, Kayon position leans more to one side. The palemahan (base) of the Kayon connected with lengkeh. The base is colored yellow and green and is connected to

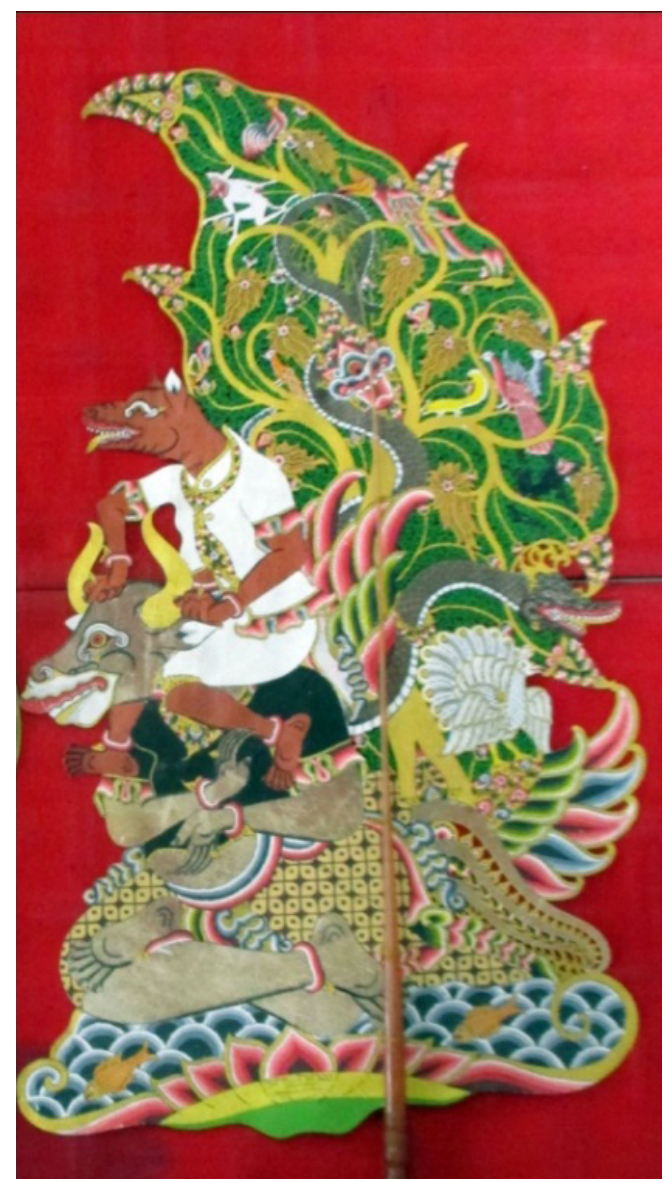

Figure 8. Kayon Sona Srenggala, Bambang Suwarno collection. (Source: Bagaskoro Ardhi, 2018) the ornate shape of the lotus. At the bottom there is an ornamental form with the shape of blumbangan (pond) with two stilation fishes facing to the left. There is an animal-headed human form in the left position, in the form of a bull sitting in cross-legged position, dressed in black, wearing kace necklace, wearing a kawung type of fabric, buffalo dominance with a transparent form of leather utilization, and a dog-headed human riding a buffalo, dressed in white, wearing ulur-ulur necklace shaped like a tie, mouth open, tongue sticking out, dominated with the color of copper red dog.

Gunungan or Kayon Sona Srenggala has the form of buffalo-headed human being driven by a dog-headed human. The meaning contained in Kayon Sona Srenggala is a clever, cunning, resourceful person who regulates, controls, fools the lazy and stupid people.

\section{Conclusion}

The term wayang in Malayan is called "bayangbayang" (shadow). Wayang in Javanese means "shadow". Wayang also have a role as a "living encyclopedias". Wayang has been established by the United Nations through UNESCO on November 7, 2003, as the Masterpiece of the Oral and Heritage of Humanity, because wayang is considered to have high values for human civilization. Bambang Suwarno is a puppet master figure and plays the role as a puppetry teacher. Bambang Suwarno also played a role in developing pakeliran padat. His creative works are shown in a variety of puppet works, from the threshold condition, chaos, and trying something that does not yet exist from various types of puppet characters. Recognition and response of the various puppet masters of the creative work of Bambang Suwarno show that he has the creativity in his work, concepts, and supporting performances of pakeliran. Wayang is expected to be increasingly beautiful in appearance, be a liaison between the characters in the play, meet the garap Sanggitpakeliran (the grand performance), increase the treasury of the puppet characters, and strengthen the recognition of wayang in the eyes of the world. 


\section{Acknowledgements}

This writing can be completed thanks to the speakers involved in it. Therefore, the author is really thankful towards Ki Bambang Suwarno, Ki Manteb Soedharsono, Ki Purbo Asmoro, Ki Blacius Subono, Ki Suluh Juni Arsah, Ki Rudy Wiratama, and Pak Narimo. Ki Bambang Suwarno as the key speaker. Ki Manteb Soedharsono as a leading puppet master, senior, has worked closely with Ki Bambang Suwarno through pakeliran padat. Ki Purbo Asmoro, Ki Blacius Subono represented the puppet masters. Ki Suluh Juni Arsah and Ki Rudy Wiratama as young puppet masters and students of Ciptoning Studio. While Pak Narimo, is a mask artist who had been a student and was inspired by Bambang Suwarno's work.

A big thank you to the editor of the Journal of the Urban Society's Art of Indonesian Institute of the Art in Yogyakarta as a means in developing the information, knowledge, and contributing data for writing and further research.

\section{References}

Budiyatmi. (2004). Inovasi Kayon Wayang Kulit Purwa Bambang Suwarno: Kajian Bentuk, Ornamen, Rupa dan Simbol Kayon (Tesis). Surakarta: Program Pascasarjana Institut Seni Indonesia Surakarta.

Bungin, Burhan. (2007). Penelitian Kualitatif: Komunikasi, Ekonomi, Kebijakan Publik, dan Ilmu Sosial lainnya (Edisi Kedua). Jakarta: Kencana.

Dyah Pandanwangi, Wiekandini dan Farida Nuryantiningsih. (2018). "Komik Wayang Anak Pandawa sebagai Media Pendidikan Karakter di Jaman Kekinian” dalam Journal of Urban Society's Arts Volume 5 Nomor 1, April 2018:1-10. http://journal.isi.ac.id/ index.php/ JOUSA/article/view/2208/907. (Diunduh pada 24 April 2019 pukul 19.51).

Evans, James R. (1991). Berpikir Kreatif dalam Pengambilan Keputusan dan Manajemen (penerjemah Bosco Carvalho). Jakarta: Bumi Aksara

Gie, The Liang. (2004). Filsafat Seni: Sebuah
Pengantar. Yogyakarta: Pusat Belajar Ilmu Berguna.

Haryanto, S. (1988). Pratiwimba Adiluhung: Sejarah dan Perkembangan Wayang. Jakarta: Djambatan.

Haryanto, S. (1991). Seni Kriya Wayang Kulit. Jakarta: Pustaka Utama Grafiti.

Kurniawan, Didik. (2008). Kehidupan Bambang Suwarno dalam Dunia Pedalangan: Sebuah Biografi (Skripsi Program Studi S1 Jurusan Pedalangan). Surakarta: Institut Seni Indonesia.

Masroer Ch Jb. (2015). "Spiritualitas Islam dalam Budaya Wayang Kulit Masyarakat Jawa dan Sunda" dalam Jurnal Ilmiah Sosiologi Agama Volume 9 Nomor 1 JanuariJuni 2015. http://ejournal.uin-suka.ac.id/ ushuluddin/SosiologiAgama/article/ download/091-03/1045. (Diakses pada Jumat, 9 November 2018 pukul 22.00)

May, Rollo. (2004). Apakah Anda Cukup Berani untuk Kreatif (The Courage to Create). Jakarta: Teraju.

Moleong, Lexy, J. (2013). Metodologi Penelitian Kualitatif(Edisi Revisi). Bandung: PT Remaja Rosdakarya.

Mulyono, Sri. (1978). Wayang: Asal-Usul, Filsafat, dan Masa Depannya. Jakarta: BP Alda.

Nurgiyantoro, Burhan. (2011). "Wayang dan Pengembangan Karakter Bangsa" dalam Jurnal Pendidikan Karakter, Tahun 1, Nomor I, Oktober 2011. https:/ljournal.uny.ac.id/ index.php/jpkalarticleldownload/1314/1092 (Diunduh pada 24 Februari 2019 pukul 18.35).

Purwadi. (2007). Seni Pedhalangan Wayang Purwo. Yogyakarta: Panji Pustaka.

Setiadi, Bram dan Amin Pujianto. (2011). Dalang$K u$. Jakarta: CV Cendrawasih Asri Kencana, Sekretariat Nasional Pewayangan Indonesia (Sena Wangi), Pusat Data Wayang Indonesia (PDWI).

Soetarno, Sarwanto, dan Sudarko. (2007). Sejarah Pedalangan. Surakarta: CV Cendrawasih.

Sudjarwo, Heru S., Sumari, dan Wiyono, Undung. (2010). Rupa dan Karakter Wayang Purwa. Jakarta: Kaki Langit Kencana. 
Sumardjo, Jakob. (2000). Filsafat Seni. Bandung: ITB Bandung.

Sunarto. (2006). "Pengaruh Islam dalam Perwujudan Wayang Kulit Purwa" dalam Ars Jurnal Seni Rupa \& Desain Nomor 3 November 2006. http://www.researchersworld.com/vol4/ issue3/vol4_issue3_1/Paper_07.pdf (Diunduh pada 23 Nov 2018, pukul 19.34)

Suparlan, YB. (1988). Kamus Kawi-Indonesia. Yogyakarta: Kanisius.

Sutarno, Sutrisno, Bambang Murtiyoso, Bambang

Suwarno, Sarwanto, Sudarko, Catur Tulus, Sukardi, Sumanto, Rahayu Supanggah. (1978/1979). Wanda Wayang Purwa Gaya Surakarta. Surakarta: Proyek ASKI Surakarta Proyek Pengembangan IKI Departemen P dan K.

Sutopo, H.B. (2002). Metodologi Penelitian Kualitatif (Dasar Teori dan Terapannya dalam Penelitian). Surakarta: Sebelas Maret University Press.

Susanto, Mikke. (2011). Diksi Rupa: Kumpulan Istilah dan Gerakan Seni Rupa (Edisi Revisi). Yogyakarta: Dicti Art dan Djagat Art House. Suseno, Bayu Aji. (2014). "Eksistensi Seni Grafis dalam Kesenirupaan Yogyakarta" dalam Journal of Urban Society's Arts Volume 1 Nomor 2, Oktober 2014:110-120.

Suwarno, Bambang., Trisno Santoso, Purwadjito, B Djaka Susena. (1996). Berbagai Kajian Estetik Pedalangan Wayang Kulit Purwa: Kumpulan
Makalah. Yogyakarta: Program Pasca Sarjana Universitas Gadjah Mada.

\section{Informants}

Bambang Suwarno (68 years old). An artist and Puppetry teacher, lives in Surakarta, Central Java (key speaker).

Blacius Subono (65 years old). An artist, puppet master, and gamelan composer, lives in Surakarta, Central Java.

Manteb Soedharsono (71 years old). A puppet master, Plenary lecturer, and a master of puppetry in Indonesian Institute of the Arts Surakarta, lives in Karanganyar, Central Java.

Narimo (54 years old). A mask artist, student of Bambang Suwarno, lives in Sukoharjo, Central Java.

Purbo Asmoro ( 57 years old). A puppet master and a lecturer in the Department of Puppetry in Indonesian Institute of the Arts Surakarta, lives in Surakarta, Central Java.

Rudy Wiratama (30 years old). A puppet master and a student of Ciptoning Studio run by Bambang Suwarno, lives in Surakarta, Central Java.

Suluh Juni Arsah (33 years old). A puppet master and a student of Ciptoning Studio run by Bambang Suwarno, lives in Surakarta, Central Java. 